\title{
BAHAN AJAR AUDIO VISUAL SEBAGAI BAHAN VISUALISASI UNTUK PENDIDIKAN ILMU BIOMEDIK DASAR HISTOLOGI: RESENSI BAHAN AJAR
}

\author{
Kesih Kalua, Elisabeth Rukmini \\ Medical Education Unit (MEU) Fakultas Kedokteran Universitas Katolik Indonesia Atma Jaya
}

\author{
IDENTITAS BAHAN AJAR \\ Judul : Visual Basic Medicine Vol.1: Cell and Tissue \\ Edisi : 2nd Edition \\ Supervisor $\quad$ : Kazunori Ishimura, M.D., Ph.D. Univ. of Tokushima \\ Academic Support : Masako Mitsumata, M.D., Ph.D. Nihon Univ \\ Materrial Support : Toshihiko Iwanaga, M.D., Ph.D. Hokkaido Univ.,Takao Inoue, M.D., Ph.D. \\ Tottori Univ. \\ Supervisor (English) : J. Hurley Myers, Ph.D. Southern Illnois Univ. \\ Durasi : 51 menit \\ Negara : United States \\ Bahasa : Inggris \\ Distributor : : DxR Development Group, Inc. \\ Produksi : Institute of A-V Medical Education, Inc.
}

\section{DESKRIPSI BAHAN AJAR}

Salah satu dari 13 seri Medical Education, Visual Basic Medicine Vol. 1: Cell and Tissue, hadir sebagai alternatif pembelajaran yang menyenangkan sekaligus mendidik dalam memperdalam wawasan mengenai sel dan jaringan tubuh manusia. Di awal tampilannya, penonton diajak untuk berkenalan dengan komponen terkecil manusia yaitu sel. Struktur dasar sel terdiri atas dua penyusun penting yaitu nukleus dan sitoplasma. Pada sitoplasma terdapat organel-organel sel dan membran plasma. Membran plasma tersusun atas fosfolipid bilayer yang memiliki sifat hidrofobik di dalam dan hidrofilik di bagian luar. Karakteristik membran plasma inilah yang menjadikan suatu sel berfungsi sebagai jalan keluar masuknya zat secara langsung maupun tidak langsung. Glukosa, asam amino, Na, dan K tidak dapat melewati membran dengan sendirinya, sehingga perlu dibantu oleh protein channel dan sistem ini disebut transpor pasif. Pengenalan akan sel kemudian berlanjut pada aktivitasnya. Siklus sel terdiri dari fase S saat terjadi replikasi DNA, fase $\mathrm{M}$ saat terjadi mitosis diikuti dengan terjadinya sitokinesis dan menghasilkan dua sel anak yang identik, fase G1 merupakan tahap pertumbuhan sel dan ukuran sel membesar, serta fase G2 saat sel telah tumbuh sempurna dan siap melakukan pembelahan.

Dalam video berdurasi 51 menit ini dijelaskan juga mengenai jaringan. Jaringan pada manusia terdiri dari empat macam, yaitu jaringan epitel, penghubung atau penyokong, otot serta jaringan saraf. Jaringan epitel berfungsi melapisi permukaan tubuh dan organ tubuh seperti lambung dan usus. Darah dan tulang merupakan bagian dari jaringan penghubung dan penyokong. Sistem pada jaringan saraf menjadi komponen yang penting dalam menyampaikan informasi dan koordinasi antar bagian tubuh. Terdapat juga tiga jenis jaringan otot, yaitu otot polos, otot tulang dan otot jantung. Fungsi tiap macam jaringan otot pun berbeda sesuai dengan karakteristik dan letaknya. 
Kazunori Ishimura, Professor dari Institusi Kesehatan Biosains, memikirkan dengan sungguh-sungguh cara menyampaikan informasi yang berkualitas dengan menyenangkan sehingga penonton dengan mudah menangkap materi penting yang terkandung di dalamnya. Penggambaran setiap proses secara mendetil dilengkapi penjelasan yang singkat dan padat, menjadi daya tarik yang membekas dalam benak penonton.

\section{PEMBAHASAN}

Pembelajaran melalui materi Audio-Visual ini akan menarik perhatian bagi para pendidik di dunia medis. Mahasiswa kedokteran tahun pertama dapat memanfaatkan materi AV ini sebagai batu loncatan untuk adaptasi dengan suasana pembelajaran yang baru. Metode belajar dengan AV dapat dilakukan melalui permainan (Game Based Learning). ${ }^{1}$ Bagi mahasiswa kedokteran tahun pertama, materi AV ini akan sangat membantu pada blok-blok di semester awal perkuliahan, terlebih saat menghadapi blok ilmu biomedik dasar yang banyak membahas mengenai konsep-konsep dasar penyusun manusia, mulai dari histologi sel dan jaringan, materi penyusun sel, serta fisiologi sel dan jaringan.

Tidak hanya bermanfaat bagi mahasiswa tahun pertama, para tenaga pendidik dan dosen dapat memperoleh pandangan yang jelas mengenai ilmu biomedik dasar ini dengan elemen multimedia. Gaya mengajar dengan komunikasi satu arah saja antara dosen dan mahasiswa dinilai sebagai pembelajaran yang pasif dan cenderung mengarah pada kejenuhan mahasiswa. Mengatasi hal tersebut, para pendidik dapat mengimplementasikan bahan ajar multimedia dengan beragam kombinasi mengajar seperti animasi, teks, dan warna yang membantu meningkatkan nilai akademis dan ketertarikan mahasiswa. ${ }^{2}$ Terdapat tiga jenis materi multimedia; berupa tampilan teks dan image-based, video-based, serta animasi interaktif. Hasil studi menunjukkan bahwa materi multimedia videobased menghasilkan performa belajar terbaik dan paling positif untuk seseorang dengan gaya belajar audio, visual maupun audio-visual. ${ }^{3}$

Selama penayangan materi AV ini, ditampilkan video animasi dari setiap penggambaran proses fisiologi sel, seperti proses replikasi dan sintesis DNA. Tidak hanya animasi yang mudah dimengerti, bentuk setiap organ sel juga digambarkan jelas menggunakan warna yang menarik, video ini juga dilengkapi teks penjelasan pada setiap bagian dan proses yang terjadi, seperti misalnya, teks nama bagian setiap organ sel yang ditunjuk dan teks penjelasan mekanisme serta elemen yang terlibat dalam sintesis dan replikasi DNA. Hal ini memudahkan mahasiswa dengan kemampuan visual untuk memahami dan menyimpan informasi. ${ }^{4}$ Mahasiswa yang auditori juga dapat memanfaatkan materi AV ini dalam membantu proses belajar, karena materi AV menyediakan informasi yang disertai dengan background music dan suara sang narrator yang tegas dan jelas sepanjang penayangan video. Oleh karena itu, dosen dapat menjadikan materi AV ini sebagai alternatif yang efektif dari variasi gaya mengajar untuk mahasiswa pre-klinik, khususnya bagi mahasiswa dengan kemampuan audio, visual, maupun keduanya. ${ }^{5}$

Gaya belajar seseorang dibedakan berdasarkan modalitas sensorik yang berkaitan dengan pengolahan informasi. ${ }^{6}$ Terdapat empat gaya belajar, terdiri dari Visual (V), Audio (A), Read/Write (R), dan Kinestetik (K). Seseorang dengan gaya belajar yang visual akan melibatkan daya indra penglihatan mereka dalam menangkap informasi, sedangkan seseorang dengan kemampuan audio lebih mudah menangkap informasi berdasarkan dari apa yang didengarnya. Seseorang bisa dominan dalam gaya belajar unimodal, berarti menyerap materi hanya melalui satu gaya belajar seperti visual saja atau audio saja. maupun dalam gaya belajar multimodal yang menggabungkan dua atau lebih gaya belajar.

Diantara gaya belajar yang multimodal, bimodal adalah yang paling banyak diterapkan oleh mahasiswa, salah satunya audio-visual. Sebuah studi yang dilakukan pada mahasiswa kedokteran menunjukkan 63,8\% memiliki gaya belajar yang multimodal. ${ }^{7}$ Berdasarkan hasil survei, mahasiswa sangat menyukai pembelajaran yang melibatkan elemen multimodal dan merasa bahwa hal ini sangat membantu dalam memahami dan menyimpan materi. $^{8}$ Materi Audio-Visual membantu dosen menciptakan suasana belajar mengajar yang kondusif dan dinamis di antara mahasiswa serta menggali gagasan mahasiswa untuk aktif berpikir tentang materi yang dibahas. 
Materi Audio-Visual dapat menjadi sarana belajar mandiri yang tepat bagi mahasiswa, karena pembelajaran dengan elemen multimodal seperti materi AV dapat dilakukan di luar kelas atau jam perkuliahan oleh mahasiswa yang mendukung proses belajar disaat jarak dan waktu pertemuan antara dosen dan mahasiswa tidak memungkinkan. Desain pembelajaran di era teknologi modern saat ini melalui materi Audio-Visual yang turut disertakan dengan pemberian tugas mandiri oleh dosen mendukung terciptanya proses belajar yang berpusat pada mahasiswa. Dosen tidak hanya memberikan kuliah, tetapi berperan dalam merancang metode pengajaran yang merangsang ketertarikan mahasiswa dan mengembangkan wawasan lebih dari pemberian materi di jam perkuliahan.

Dalam proses belajar mandiri menggunakan teknologi, dosen dapat mengawasi dan memberikan arahan. Pertama, dosen dapat memberikan gagasan dasar dan beberapa contoh sederhana, lalu memberikan tugas pada mahasiswa untuk mencari dan mengembangkan sendiri wawasan dari referensi yang ada berdasarkan pemikiran kreatif mahasiswa. Dosen dapat membagi kelompok belajar sebagai sarana untuk berdiskusi dan menyampaikan hasil belajar antar mahasiswa. Berdasarkan hasil studi, audio-visual berdampak $20 \%$ pada peningkatan pemahaman, diskusi kelompok 50\%, pengalaman melakukan langsung 75\%, membagi ilmu pada orang lain 90\%, sedangkan kuliah materi hanya berdampak $5 \%{ }^{9}$

Para pendidik dapat menggunakan desain belajar interaktif digital menggunakan gambar, video, audio yang melibatkan peran langsung mahasiswa belajar aktif, kolaborasi dengan kelompok, dan kehendak personal yang berkontribusi pada perkembangan pola pikir yang multiple dan gaya belajar yang melibatkan pengalaman verbal dan visual. ${ }^{10}$ Desain pembelajaran seperti ini mendorong mahasiswa terlibat langsung dalam proses belajar serta menyimpulkan gagasan berpikir baik untuk pribadi maupun berbagi dengan mahasiswa lain, sehingga kuliah tidak hanya penyampaian informasi yang pasif oleh dosen kepada mahasiswa.

Penelitian neuroscience menunjukkan bahwa peningkatan yang signifikan pada pembelajaran individu terjadi saat suasana belajar sesuai dengan gaya belajar individu yang dominan. ${ }^{11}$ Pengetahuan akan gaya belajar mahasiswa memberi implikasi bagi pendidik bidang kesehatan dan kedokteran, maupun bagi mahasiswa sendiri. Mahasiswa yang mengetahui gaya belajar dominan mereka, dapat membantu dirinya sendiri dan kelompoknya dalam strategi belajar yang efektif untuk memaksimalkan potensi mahasiswa dan memotiasi mahasiswa mencapai sukses akademis. Perbedaan dalam gaya belajar setiap individu menunjukkan perbedaan kebutuhan dalam proses belajar. Hal ini dapat berhubungan langsung dengan performa hasil belajar mahasiswa, pemahaman yang mendalam, dan potensi pencapaian kesuksesan lebih tinggi. ${ }^{12}$

Tujuan suatu pembelajaran adalah memfasilitasi mahasiswa untuk dapat belajar lebih efektif. Pembelajaran dengan teknologi dalam pendidikan kedokteran ditemukan mengembangkan pengetahuan dengan efektif. ${ }^{13}$ Namun, metode belajar dengan audio-visual harus dilaksanakan oleh para pendidik kesehatan dengan memahami prinsip pembelajaran yang baik. ${ }^{14}$ Kesesuaian antara pengajar dan gaya belajar mahasiswa akan sangat berdampak untuk menolong para pendidik dalam memfasilitasi mahasiswa menjadi lebih cakap. Penggunaan teknologi dalam mengajar seperti melalui materi audio-visual akan membantu tenaga pendidik dalam menciptakan atmosfir belajar yang interaktif.

Pendekatan materi pembelajaran yang bertujuan untuk memenuhi sasaran belajar terkadang mengalami kendala seperti ketersediaan teknologi dan keterbatasan bahasa ${ }^{15}$, sehingga perubahan gaya mengajar yang teacher-centred ke gaya mengajar yang student-centred kurang terealisasi dengan baik. Perbedaan gaya belajar pada mahasiswa sangatlah penting disadari oleh para pendidik. Dengan mengetahui kemampuan mahasiswa yang berbedabeda, pendidik dapat menyediakan informasi yang membangun pembelajaran efektif, mencoba metode pembelajaran yang baru dan tidak terpaku pada satu gaya mengajar untuk menyeimbangkan dengan kebutuhan mahasiswa yang memiliki gaya belajar yang berbeda-beda.

Don't judge a book by its cover mungkin menjadi slogan yang pas untuk materi pembelajaran AV ini. Dibalik penampilan cover yang sederhana dan 
terkesan kurang menarik, terkandung materi yang sangat memikat dan tentunya memberikan manfaat besar bagi penonton. Masako Mitsumata bersama tim mampu menciptakan atmosfer ilmiah dengan mengemas seluruh informasi dan pengetahuan dalam bentuk animasi yang menarik dan mudah dimengerti tanpa menomorduakan kualitas dari isi informasi yang ingin disampaikan kepada penonton.

\section{DAFTAR PUSTAKA}

1. Pitt MB, Borman-Shoap EC, Eppich WJ. Twelve tips for maximizing the effectiveness of game-based learning. Med Teach. 2015:1013-7.

2. Zin MZM, Latif MSA, Bhari A, Sulaiman R, Rahman AA, Mahdi AF, et al. Education quality enhancement via multimedia technology. Asian Soc Sci. 2012:1037.

3. Chen C-M, Sun Y-C. Assessing the effects of different multimedia materials on emotions and learning performance for visual and verbal style learners. Comput Educ. 2012:1273-85.

4. Kim D, Gilman DA. Effects of text, audio, and graphic aids in multimedia instruction for vocabulary learning. J Educ Technol Soc. 2008:n/a.

5. Samarakoon L, Fernando T, Rodrigo C. Learning styles and approaches to learning among medical undergraduates and postgraduates. BMC Med Educ. 2013;13:42.

6. Lujan HL, DiCarlo SE. First-year medical students prefer multiple learning styles. Adv Physiol Educ. 2006:13-6.
7. Liew S-C, Sidhu J, Barua A. The relationship between learning preferences (styles and approaches) and learning outcomes among pre-clinical undergraduate medical students. BMC Med Educ. 2015:44.

8. Sankey M, Birch D, Gardiner M, Sankey M, Birch D, Gardiner M. The impact of multiple representations of content using multimedia on learning outcomes across learning styles and modal preferences. Int J Educ Dev Using ICT. 2012:18-35.

9. Lankapalli R. role of audio-visual aids in constructivist approach. Int J Appl Serv Mark Perspect. 2013:67884.

10. Bull PH. Cognitive constructivist theory of multimedia: designing teacher-made interactive digital. Creat Educ. 2013:614-9.

11. Kharb P, Samanta PP, Jindal M, Singh V. The learning styles and the preferred teaching-learning strategies of first year medical students. J Clin Diagn Res JCDR. 2013:1089-92.

12. Chessell G. Learning styles in first year medical students. Med Teach. 1986:125-35.

13. Sandars J, Patel RS, Goh PS, Kokatailo PK, Lafferty $\mathrm{N}$. The importance of educational theories for facilitating learning when using technology in medical education. Med Teach. 2015:1039-42.

14. Al-Eraky MM. Twelve tips for teaching medical professionalism at all levels of medical education. Med Teach. 2015:1018-25.

15. Urada A, Gielecki JS, Osman N, Tubbs RS, Loukas M, Urada-zieliska A, et al. The study techniques of Asian, American, and European medical students during gross anatomy and neuroanatomy courses in Poland. Surg Radiol Anat. 2011:161-9. 